Politik Indonesia: Indonesian Political Science Review 1 (1) (2016) 87-101

Politik Indonesia

Indonesian Political Science Review

http://journal.unnes.ac.id/nju/index.php/JPI

\title{
Politik dan Strategi Budaya Etnik dalam Pilkada Serentak di Kalimantan Barat
}

Kristianus $^{1 \bowtie}$

${ }^{1}$ Sekolah Tinggi Pastoral Santo Agustinus Pontianak, Indonesia

\begin{tabular}{l}
\hline Info Artikel \\
\hline Sejarah Artikel: \\
Diterima 6 Agustus 2015 \\
Disetujui 15 Desember 2015 \\
Dipublikasi 15 Januari 2016 \\
\hline
\end{tabular}

Keywords:

Politic Local; Ethnisity;

Cultural Group; Fanaticism

\begin{abstract}
Abstrak
Politik lokal di Kalimantan Barat kental bermuatan politik identitas etnik. Politik lokal yang bermuatan politik identitas ini melibatkan dua etnik yang merupakan penduduk asli di Kalimantan Barat yaitu etnik Dayak dan Melayu. Keadaan persaingan kedua etnik ini menjadi lebih terbuka pada era otonomi daerah sekarang ini yang dipicu oleh pemilihan kepala daerah secara langsung. Persaingan ini selalu terjadi karena sejarah mencatat bahwa elit etnik yang berkuasa selalu melakukan hegemoni etnik atas etnik lain. Pemilihan umum kepala daerah (PILKADA) sedang berjalan saat ini. Dari tujuh kabupaten di kalimantan Barat yang menyelenggarakan PILKADA ini sangat nampak bahwa mereka berorientasi etnisitas untuk merebut suara. Paper ini mencoba memadukan pandangan yang bersifat instrumentalism dan kolonialisme internal. Penulis memiliki pandangan, bahwa perspektif instrumentalisme mampu untuk melihat bagaimana elit memainkan identitas sosial dan budaya kelompoknya untuk mendapatkan kekuasaan dan pandangan kolonialisme internal yang melihat kesenjangan sosial-ekonomi dan perlakuan yang diskriminatif sebagai akar menguatnya solidaritas kelompok. Pandangan ini sangat membantu untuk menjelaskan factor fanatisme etnik sebagai strategi kebudayaan yang terjadi pada masa kini dan mengapa politik identitas di Kalimantan Barat merupakan bagian yang inherent dalam politik lokal masa ini.
\end{abstract}

Abstract
The Local politics in West Kalimantan thick politically charged ethnic identity. Local
political politically involved two ethnic identity which is a native of West Kalimantan,
namely ethnic Dayak and Malay. The state of the two ethnic rivalry is becoming more
open in the era of district autonomy that is triggered by direct local elections. This
competition occurs because history records that the ruling ethnic elite running
ethnic hegemony over other ethnic groups. Regional head election (PILKADA) is
currently running. Of the seven districts in West Kalimantan which organizes
PILKADA very apparent that they are oriented to capture the voice ethnicity. Ethnic
identity became a political commodity since this issue most easily sold to seize the
people's voice. This paper use the incorporation of the views that are instrumentalism
and internal colonialism perspective. The author has the view, that perspective
instrumentalism able to see how an elite play social identity and cultural group to gain
power and view of internal colonialism that saw socio-economic disparities and
discrimination as the root of the strengthening of solidarity groups. This view is helpful
to explain the fanaticism ethnic factor as a cultural strategy that occurred in the
present and why identity politics in West Kalimantan is an inherent part of the local
politics of this period.

(C) 2016 Universitas Negeri Semarar

Alamat korespondensi:

ISSN $2477-8060$

Sekolah Tinggi Pastoral Santo Agustinus Pontianak, Kompleks Perguruan, St. MonicaJl. Adisucipto

KM 9,4 Sei Raya, Kubu Raya, Pontianak, Indonesia Email: kristianusatok@ gmail.com 


\section{Pendahuluan}

Berbagai fakta menunjukkan, bahwa perubahan politik dari sistem yang lebih tiga dekade mapan (politik otoriterian) ke sistem yang demokratis di Indonesia dengan masyarakatnya yang multikultural justeru semakin menguatkan semangat primordialism. Sehingga tidak mengherankan jika di Indonesia hari ini justeru memunculkan masalah baru dalam aspek keamanan sosial, politik dan budaya masyarakatnya. Fenomena yang bisa dianggap sebagai sebuah paradoks dalam demokrasi telah wujud dalam proses demokrasi di beberapa daerah di era otonomi daerah saat ini. Etnis dan agama sebagai salah satu kategori sosial kemudian berkembang menjadi bagian terpenting dari identitas politik, dan bahkan simbol dan kategori sosial tersebut seringkali menjadi dasar legitimasi dalam persaingan politik di daerah. Maka munculah kemudian apa yang saya sebut sebagai politik etnik.

Sebagai masyarakat yang multikultural, Kalimantan Barat (Kalbar) merupakan salah satu daerah yang paling rentan dihadapkan dengan permasalahan gesekan-gesekan yang bernuansakan SARA dalam persaingan politik tersebut. Secara politis, kondisi ini muncul bisa disebabkan karena dalam waktu yang cukup lama berbagai harapan dan keinginan komunitas lokal terabaikan sebagai konsekuensi dari bangunan sistem politik dan pemerintahan yang sentralistik. Dampaknya adalah, kalaupun ada penerimaan terhadap berbagai kebijakan dan pengintegrasian nilai-nilai dan kultur yang dibentuk oleh rezim ORBA namun sesungguhnya diterima secara "terpaksa". Pendekatan human security atau keamanan masyarakat yang cenderung militeristik oleh rezim ORBA yang tidak membenarkan adanya ruang perbedaan pandangan dengan penguasa hari ini telah menjadi semacam bom politik etnik. Saat ini telah menguat kebebasan setiap kelompok untuk mengekspresikan berbagai perbedaanperbedaan kategori sosial tersebut.

Pemilihan umum kepala daerah (Pilkada) serentak tahun 2015 sedang dalam proses berjalan. Di Kalimantan Barat ada tujuh kabupaten yang menyelenggarakannya yaitu: Ketapang, Sambas, Bengkayang, Sekadau, Melawi, Sintang dan Kapuas Hulu. Dari daftar calon yang masuk pada tujuh kabupaten tersebut menampakan gejala etnisitas yang semakin menguat. Dalam perkembangan selanjutnya etnisitas bahkan sudah seperti budaya, karena sejak otonomi daerah para elite etnik telah manipulasinya sedemikian rupa dan dijadikan instrumen perjuangan politik untuk memperebutkan kekuasaan. Di Kalimantan Barat yang masyarakatnya masih kuat semangat primordialismenya, identitas etnis menjadi daya tawar yang menarik. Inilah yang kemudian saya sebut sebagai politik etnik.

Politik etnik yang membudaya ini, Di Propinsi Kalimantan Barat bahkan telah menjadi acuan dalam merubah administrasi pemerintahan. Sampai akhir pemerintahan 
rezim Orde Baru tahun 1998, propinsi ini hanya terdiri dari 7 kabupaten/ kota, namun sejak tahun 2011 jumlah kabupaten/kota telah menjadi 14 kabupaten/kota. Peningkatan ini sangat signifikan, yakni $100 \%$. Saat ini wacana pembentukan Propinsi baru yang lagi lagi berorientasi etnisitas juga semakin kencang. Kelak propinsi ini akan dinamakan Propinsi Kapuas Raya, wilayah propinsi Kapuas Raya ini meliputi kabupaten kabupaten di pedalaman seperti Sanggau, Sekadau, Sintang, Melawi, dan Kapuas Hulu yang nota bene kawasan yang didominasi oleh Etnik Dayak.

Beberapa kelompok etnik sekarang telah memiliki wilayah kekuasaan (teritori) tersendiri, misalnya Kabupaten Sambas menjadi teritori Melayu Sambas dan Kabupaten Pontianak menjadi teritori Melayu Mempawah, Bengkayang teritori Dayak Bekati, Landak teritori Dayak Kanayatn, Sekadau teritori Dayak Mualang, Melawi teritori Dayak Keninjal dan Melayu Pinoh, Kayong Utara teritori Melayu Kayong.

Adapun di Kawasan kabupaten seperti Sintang sedang berlangsung perjuangan Dayak Ketungau untuk membentuk kabupaten sendiri. Di kabupaten Kapuas Hulu Dayak Iban, Taman, Kantu dan Suhaid sedang berlomba-lomba pula memekarkan kabupaten baru. Di Kabupaten Ketapang saat ini sedang berlangsung perjuangan Dayak Simpang,dan Dayak Keriau untuk mendirikan kabupaten baru. Di kabupaten Sanggau sedang berlangsung perjuangan Dayak Bidayuh dan
Dayak Tayan untuk mendirikan kabupaten baru.

Sementara itu etnik Cina dan Madura yang terusir akibat konflik-konflik yang melibatkan mereka terkonsentrasi di sekitar perkotaan. Bersama Bugis dan Jawa, keempat kelompok etnik tersebut menjadi mayoritas di beberapa lokasi kota perdagangan penting di Kalbar seperti Kubu Raya, Kota Pontianak dan kota Singkawang. Adapun Singkawang telah menjadi teritori Cina Bukan hanya dari aspek demografis, melainkan juga simbolis.

\section{Kajian Pustaka}

Seorang dalam melakukan interaksi dengan sesama dalam kehidupan sosial dipengaruhi, antara lain, oleh identitas kesukubangsaannya. Dengan identitas kesukubangsaan tertentu, yang ditentukan baik untuk mengkaterogikan diri sendiri atau orang lain, seseorang dapat mengaktifkan ikatan kelompok sesama suku bangsa. Ikatan itu nantinya dapat membentuk pola tersendiri dalam hubungan interaksi dengan sesama. Itu terjadi, karena didalam ikatan kesukubangsaan bukan saja terlekat ciri budaya, melainkan juga tatanan sosial dan nilai-nilai dasar (Barth, 1969) yang terbawa sejak lahir.

Konsep identitas secara umum diartikan sebagai citra yang membedakan suatu individu/ kelompok dengan individu/ kelompok lainnya yang dibangun oleh individu/ kelompok tersebut serta dimodifikasi secara terus menerus melalui 
interaksi dengan pihak-pihak lain (Katzenstein, 1996). Menurut Baharuddin (2000), istilah identitas pada umumnya mempunyai dua pengertian, satu merujuk kepada identitas individu dan satu lagi bersifat identitas kelompok. Secara individual, setiap orang dilahirkan berbeda-beda dan memiliki ciri serta perwatakannya sendiri, maka tidaklah mengherankan setiap kali kita mengatakan tentang individu akan lebih cenderung menekankan pada ciri keunikan dan kelainan seseorang individu. Sedangkan identitas kolektif lebih menekankan kepada ciri persamaan dalam sebuah kelompok, seperti bahasa yang dipertuturkan, sifat kebudayaan, dan agama yang dianut. Timbulnya keinginan mewujudkan identitas kelompok mungkin datang dari dalam sesuatu kelompok itu sendiri yang dimotivasi oleh dorongan kekitaan, rasa keistimewaan dari dan atau komunalisme. Namun juga sering terjadi bahwa munculnya identitas kelompok dari hubungan timbal-balik pegaruh luar dan internal yang terjadi secara serentak akibat dari faktor sejarah, politik, ekonomi, agama dan lainnya.

Dalam bidang ilmu kemasyarakatan dan kemanusiaan sekitar pada tahun 1950-an dan 1960-an, terdapat tiga bentuk tradisi atau pendekatan dalam pembicaraan mengenai identitas, yaitu yang bersifat psikodinamika, sosiologikal dan sosio-politik. Tradisi psikodinamika muncul dari tradisi Sigmund Freud, seseorang ahli psikologi, yang berdasarkan pada theory of identification.
Teori ini menganjurkan pandangan bahwa identitas individu adalah dibentuk melalui proses asimilasi dan penghayatan objek dan personalitas diluar individu. Pandangan Freud ini kemudian dikembangkan oleh Erik Erikson (1968) dengan teori psikodinamik. Tradisi Sosiologikal yang dikembangkan oleh Goerge H. Mead (1934) Dengan pendekatan symbolic interactionisme, pula membicarakan tentang individu dari sudut pembentukan dan penguraian konsep self atau diri seseorang individu. Pakar-pakar sosiologi memberikan pendapat bahwa manusia mampu berkomunikasi antar satu sama lain dengan menggunakan bahasa. Melalui kemampuan itu, manusia sebagai individu dapat mengenal dan menilai diri masing-masing.

Maka identitas manusia yang mempunyai diri dikenal melalui nama, gelar, watak social dan berbagai kategori sosial yang manusia cipta sendiri untuk memudahkan komunikasi sesama mereka. Tradisi sosio-politik yang dikembangkan oleh Ernes Gellner dalam bukunya Nations and Nationalism (1983), Benedict Anderson dalam bukunya Imagined Communities (1983), Anthoni D. Smith dalam bukunya National Identitas (1986), memaknai identitas, khususnya identitas kolektif, telah berkembang bersama dengan gerakan nasionalisme untuk menuntut kemerdekaan di wilayah tanah jajahan colonial, terutamanya setelah Perang Dunia Kedua (Baharuddin, 2000). 
Dalam pandangan sosio-politik, konsep identitas sering dikaitkan dengan konsep nation atau bangsa, karena diandaikan bahwa sesuatu bangsa itu wujud setelah identitasnya ditentukan. Maka pembangunan bangsa dianggap sekaligus sebagai usaha membangun identitas bangsa, atau identitas nasional, suatu entiti sosial yang bersifat kolektif. Identitas kolektif tersebut terbentuk berdasarkan kerjasama faktor bahasa, agama, budaya dan etnik yang diterima sebagai gugusan faktor yang dapat membangun identitas . Pengunaan identitas kolektif sebagai sumberdaya sekaligus sebagai sasaran politik di dalam realitas modern, secara sederhana boleh kita temukan di dalam fenomena terbentuknya "Negara-bangsa" (nation-state) dalam era poskolonial, di mana kemajemukan latarbelakang komunitas seperti ras, suku-bangsa (etnik), agama membentuk komunitas Negara-bangsa. Konsepsi seperti inilah yang dikemukakan oleh Benedict Anderson (1983) melalui tesisnya mengenai "imagined communities", dimana ikatanikatan kolektif dalam suatu komuniti politik bukan hanya suatu konstruksi politik saja, akan tetapi juga sebagai konstruksi budaya. Disini, ikatan terhadap kolektivitas bukan lagi di dasari oleh kotak-kotak langsung secara fisik sebagaimana yang membuat kita terikat dengan komunitas di lingkungan sekitar (neighbourhood) atau di dalam suatu organisasi. Melainkan "diciptakan” oleh makna yang diproduksi melalui symbolsimbol dan praktek-praktek budaya yang saling dibagi bersama. Seperti penulisan sejarah, lagu-lagu kebangsaan, bendera, atau pengakuan bagi hari-hari besar nasional.

Penelusuran terhadap makna dan konsep identitas merupakan suatu usaha yang seringkali berterusan. Kata identitas sendiri boleh merujuk pada konotasi social, politik, budaya, agama dan seumpamanya. Pencaharian tentang identitas sangat berhubungrapat dengan masalah humaniti dan psikologi manusia, makana identitas dapat dikaji dalam psikologi yang disebut dengan teori identitfikasi (theory of identification) yang dikemukakan oleh Sigmun Freud (1986). Hal paling penting daripada identifikasi ini menurutnya adalah, seseorang lebih Berjaya bila menjadi identifikasi parsial, dan ia menjadi representasi permulaan sesuatu ikatan baru. Freud dalam teori psikoanalisisnya mencadangkan kajiannya tentang identitas dengan konsep ego (identitas ego). Menurutnya ego merupakan bahagian terpenting daripada seluruh kepribadian (personalitu). Proses identifikasi diri (ego) sesungguhnya dimulai sejak kecil sampai pada penemuan identitas, oleh karena itu, dasar kajian identitas freud berpunca daripada konsepnya tentang ego. Penemuan identitas juga terjadi dalam proses social dan aspek "sosio" dari pada identitas harus dijalankan dalam kelompok sosial dari individu berkenaan.

Kemudian dengan berdasarkan pada analisis psikoanalisis, Erikson (1989) juga berpendapat bahwa formasi identitas adalah 
proses perkembangan dan adaptasi yang inheren pada setiap orang dan identitas ego merupakan bahagian eksistensial daripada manusia. Dia menyatakan bahwa formasi identitas sebagai suatu configuration yang berkembang secara bertahap mengintegrasikan keperluan-keperluan dasar. Configuration yang berkembang tersebut kemudian merespon pada gerak terdalam dan tekanan-tekanan sosial yang mengubah siklus kehidupan seseorang. Erikson juga berpendapat bahwa sebenarnya identitas ego seringkali dan pasti dipengaruhi oleh hubunga social dan sejarah. Identitas ego dalam aspek subjektif pada asasnya juga merupakan kesedaran tentang realitas mencari pengertian identitas melelui cara identifikasi dapat dihubungkaitkan secara sosisal. Kehidupan social itu sendiri menurutnya dimulai daripada permulaan hidup setiap individu. Ientiti mempunyai konotasi sebagai adanya kesamaan dalam diri sendiri (self sameness) yang sifatnya permanent mahupun sesuatu pembahagian karakter yang sangat esensial dengan orang lain yang sifatnya juga permanen.

\section{Pemahaman konseptual tentang} identitas dalam perspektif psykologis tersebut tentunya bermanfaat untuk memberikan gambaran bahwa pada dasarnya setiap orang akan terus mengidentifikasikan dirinya, mencari diri dan membentuk identitas, karena identitas sendiri secara psykologi merupakan proses menjadi dan bersifat imperaktif. Dalam konteks inilah menurut Isaac (1975) secara social dan budaya memunculkan wujudnya suatu bentuk pemujaan terhadap identitas yang didasarkan pada kelompok etnik. Dalam masyarakat yang majmuk, etnisitas telah manjadi sentiment ego dan menjadi penggerak individu-individu dan kelompok yang membentuk kesedaran kolektif budaya dan politik.

Identitas menurut Jonathan Rutherford (Piliang, 2004) merupakan sebuah talian yang menghubungkan nilai-nilai sosial budaya masa lepas dengan masa sekarang. Ertinya identitas memiliki sejarahnya dan merupakan ikhtisar masa lepas yang membentuk masa sekarang dan untuk kepentingan di masa hadapan. Dalam konteks social, identitas merupakan sesuatu yang dipunyai secara bersama-sama oleh suatu komuniti atau kelompok masyarakat tertetentu, yang membedakan (difference) mereka dari kelompok masyarakat yang lainnya. Identitas juga memberikan tanda kepada setiap individu atau kelompok mengenai status social mereka di antara berbagai kelompok masyarakat lainnya. Disinilah yang menjadikan identitas di pandang sebagai unsure penting dalam pembentukan realitas sosial.

\section{Kajian Pustaka}

Metodologi

Metode yang digunakan dalam penelitian ini adalah kualitatif analitik. Dimana data yang diperoleh dari Komisi Pemilihan Umum baik tingkat Provinsi 
maupun Kabupaten pada tujuh Kabupaten dianalisis dengan menelusuri latar belakang etnisitas dan agama para calon. Penelusuran ini dilakukan berdasarkan wawancara dengan nara sumber yang dianggap kompeten dari tujuh kabupaten berkenaan. Analisis data selain berdasarkan data KPUD, dan informan juga memperhatikan informasi pemberitaan di koran-koran lokal seperti Pontianak Post, Pontianak tribun, Tribun Pontianak, Equator dan Kapuas post.

\section{Temuan dan Diskusi}

Etnisitas dalam Politik Lokal Kalimantan Barat

PILKADA serentak 2015 di tujuh kabupaten di Kalimantan barat sudah melewati babak penetapan calon dan penetapan nomor urut calon. Saat ini proses tersebut sedang memasuki tahap kampanye. Daftar calon dari tujuh kabupaten tersebut sebagai berikut, lihat tabel 1 berikut ini.

Tabel 1. Daftar Calon Bupati/Calon Wakil Bupati Pilkada Serentak Pada 7 kabupaten di Kalimantan Barat.

\begin{tabular}{|c|c|c|c|c|}
\hline No & Kabupaten & $\begin{array}{l}\text { No } \\
\text { Urut }\end{array}$ & $\begin{array}{c}\text { Nama Calon Bupati } \\
\text { dan Nama Calon } \\
\text { Wakilnya }\end{array}$ & Etnis \&agama \\
\hline \multirow[t]{4}{*}{1} & Benglayang & 1 & Sebastianus Darwis & Dayak/Katolik \\
\hline & & & Rurakhmad & Dayak/Katolik \\
\hline & & 2 & Suyatman Gidot & Dayak/Protestan \\
\hline & & & Agustinus Naon & Dayak/Katolik \\
\hline \multirow[t]{6}{*}{2} & Sambas & 1 & Toni Kumiadi (lk) & Melayu/Islam \\
\hline & & & Eka Nurhayati (pr) & Melayu/slam \\
\hline & & 2 & $\begin{array}{l}\text { Atbah } \\
\text { RotminSuahili (lk) }\end{array}$ & Melayu/Islam \\
\hline & & & Hairiah(pr) & Melayu/slam \\
\hline & & 3 & Juliarti Alwi (pr) & Melayu Islam \\
\hline & & & Hasamusi (lk) & Melayu/slam \\
\hline \multirow[t]{6}{*}{3} & Sekadau & 1 & H. Pensong & Melayu Islam \\
\hline & & & Christian Amon & Dayal/ Kristen \\
\hline & & 2 & Rupinus & Dayal/Katolik \\
\hline & & & Aloysius & Dayak/Katolik \\
\hline & & 3 & Simson & Dayal/Kristen \\
\hline & & & Paulus Subamo & Dayalk/Katolik \\
\hline \multirow[t]{6}{*}{4} & Sintang & 1 & Agriamus & Dayal/Katolik \\
\hline & & & Muhamad C Wahap & Melayu/Islam \\
\hline & & 2 & Ign Yuan & Dayak/Katolik \\
\hline & & & Senen Maryono & Jawa/Islam \\
\hline & & 3 & Jarot Winamo & Jawa Islam \\
\hline & & & Askiman & Dayak/Kristen \\
\hline
\end{tabular}

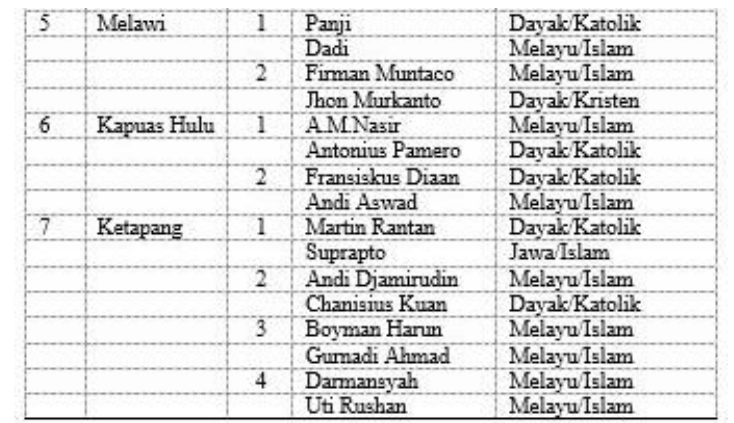

Sumber : KPU Provinsi Kalbar, 2015.

Dari daftar calon tersebut sangat jelas bahwa semua penentuan calon oleh partai politik maupun perseorangan berorientasi etnisitas. Untuk kasus kabupaten Bengkayang dan Sambas misalnya, kedua kabupaten ini dulunya adalah satu, yaitu kabupaten Sambas. Pemecahan wilayah dilakukan terkait etnisitas, dimana Bengkayang didominasi etnik Dayak dan Sambas oleh etnik Melayu. Di kedua kabupaten ini semua calonnya dari etnik yang sama, yang kemudian terjadi adalah pertimbangan berdasarkan faktor agama (Katolik dan Kristen) untuk kasus Bengkayang dan faktor gender untuk kasus Sambas. Di Sambas semua calon menyandingkan laki-laki dan perempuan (lihat tabel 1).

Di lima kabupaten lainnya, pasangan calonnya berasal dari etnik Dayak, Melayu dan Jawa. Di Kabupaten Melawi, Sekadau dan Kapuas Hulu, penentuan pasangan calonnya adalah pasangan Dayak-Melayu atau MelayuDayak, sedangkan di kabupaten yang banyak lokasi transmigran Jawa seperti di Sintang dan Ketapang, maka pasangannya adalah DayakJawa atau Jawa-Dayak disamping tentu saja 
pasangan Dayak-Melayu atau Melayu-Dayak itu tadi.

Politik Etnis dalam Pilkada, ternyata bukan hanya terjadi di Kalimantan Barat. Hal demikian ditemukan pula pada Pemilihan Gubernur (Pilgub) Bengkulu tahun 2005 (Firmansyah, 2010), pada Pemilihan Kepala daerah (Pilkada) Kabupaten Poso Sulawesi Tengah tahun 2010 (Nawawi, dkk, 2011), pada Pilkada Kolaka Utara tahun 2012 (Ashar, 2014), dan bahkan pada Pemilihan Gubernur DKI Jakarta tahun 2012 (Adrian, 2014).

Orientasi semacam ini sudah terjadi sejak era otonomi daerah tahun 1999 dan kondisinya makin menguat sekarang. Dalam konteks politik lokal di Kalimantan Barat, perjuangan politik dengan penggunaan identitas memang membawa hasil yang nyata, dimana kabupaten yang dominan dari etnik Dayak, maka cenderung yang menang adalah elit Dayak juga. Di level Gubernur, karena yang dominan di Kalimantan Barat adalah Dayak maka sejak Pilkada langsung dilaksanakan, pemenangnya selalu dari etnik Dayak .

Fenomena ini makin tampak sangat jelas pada daerah-daerah otonom baru di Kalimantan Barat yang pembentukannya atas dasar etnik dominan. Kondisi ini kelihatannya sejalan dengan apa yang dikemukakan oleh Beyme (1996: hlm 118) ${ }^{34}$ bahwa tindakan

\footnotetext{
${ }^{34}$ Klause von Beyme (1996). Biopolitical Ideologies and Their Impact in the New Social Movenments. Dalam Biopolitic, The Politics of the Body, Race and Nature. Agnes Heller dkk (eds). Brookfield, USA: Avebury.
}

politik identitas pada hakikatnya adalah suatu gerakan social yang ingin mengubah kondisi masyarakatnya. Namun, dalam perjalanan berikutnya memang, politik identitas justru dimanfaatkan oleh kelompok majority untuk menguatkuasakan dominasi kekuasaannya. Melalui pola-pola penggunaan identifikasi kita-lawan-mereka, kelompok majority meneguhkan kembali superioritinya.

Kategorisasi gerakan politik identitas daripada Beyme ini hanya sebatas menjelaskan fenomena kecenderungan yang terjadi dalam tiga fase (pra moden, moden dan postmodern) saja, tapi tidak menjelaskan

Beyme membuat karakteristik daripada pola gerakan politik identity yaitu: pertama, gerakan politik identity pada dasarnya membangun kembali narasi besar yang prinsipnya mereka tolak dan membangun suatu teori yang mengendalikan faktor-faktor biologis sebagai penyusun perbedaan-perbedaan mendasar dalam reality kehidupannya. Kedua, dalam gerakan politik identity ada kecendrungan tertentu untuk membangun system reversed apartheid. Ketika kekauasaan tidak dapat ditaklukan dan power sharing tidak tercapai sebagai tujuan gerakan, maka pemisahan atau autonomi dan pengecualian diri dijadikan solusi. Secara history, menurut Beyme wacana gerakan sosial politik yang didasarkan pada pola politik identity dapat di bahagi melalui tiga kategori, yaitu; pertama, era pra moden, di mana wacana politik identity etnik merupakan kelompok-kelompok yang terpecah berdasarkan nasionalism etnik, belum mengenal kebudayaan. Tujuan daripada gerakan politiknya adalah kekuasaan dan dominasi atas kelompok etnik lainnya demi untuk kelangsungan hidupnya (tribalism). Peran pemimpin dalam proses ini sangat penting dan dominan. Paternalism memegang peran yang sangat penting dalam pembentukan komuniti dan masyarakatnya. Kedua, era moden, di mana gerakan politik identity peran pemimpin tidak lagi dominan, kerana sudah diikuti oleh peran dan keikutsertaan dari akar umbi yang akhirnya mengahala pada pembahagian kekuasaan. Pada fase ini pula sudah muncul ideologi, dan peran-peran besar modernism. Sedangkan yang ketiga, era postmodern, di mana gerakan politik identity ditandai dengan keterpecahan kelompok-kelompok etnik dalam berbagai bentuk, pola dan struktur budaya saling memperlihatkan dirinya. Gerakan politik dan sosial pada era ini menurut Beyme bukan pada orientasi kekuasaan untuk mendominasi, namun lebih hanya pada politik kebudayaan, kepemilikan atas hak-hak sosial, autonomi, kebebasan berekspresi dan berbudaya. 
perkembangan yang terjadi dalam masyarakat berbilang kaum yang mengamalkan system demokrasi seperti yang terjadi di Indonesia seumpamanya. Kalau melihat pembahagian yang dilakukan oleh Beyme, fenomena gerakan politik identitas di beberapa daerah di Indonesia tidaklah boleh dikategorisasikan ke dalam satu fase saja, karena ia merupakan satu gerakan yang bersifat kompeksiti. Gerakan politik identitas yang terjadi di Kalimantan Barat merupakan gabungan dari fenomena model pra moden, moden dan post moden. keadaan ini terlihat di mana tujuan gerakan politiknya selain menuntut keadilan juga ingin mendapatkan kekuasaan, ingin memperoleh hak-hak sosial, budaya politik dan ekonomi yang lebih baik. Cara-cara untuk memperoleh kekuasaan dan hak-hak tersebut dalam praktiknya juga dilakukan dengan kekerasan. Peran pemimpin atau elit tempatan sangat dominan dalam proses gerakan politik identitas tersebut.

Berhubungan dengan peran politik elit dengan perubahan politik di masyarakat, Etioni (1996) telahpun membagi masyarakat atau massa politik ke dalam tiga kategori besar yaitu, (1) Massa moral, adalah yang secara politik setia menjadi salah satu ahli politik. (2) Massa kulkulatif, adalah massa yang sangat peduli dan kritis terhadap masalah yang dialami oleh masyarakatnya. Massa ini disebut juga sebagai massa yang memiliki sifat kosmopolit. (3) Massa alienatif, adalah massa yang teralienasi dan pasrah kepada mobilisasi politik. Dalam konteks massa yang teralienasi tersebutlah menurut Etzioni peran elit untuk memanipulasi massanya menjadi penting. Dengan manipulasi symbol-simbol tertentu, elit memobilisasi massa untuk mencapai matlamat politiknya. Perasaan teralienasi yang dialami oleh suatu kelompok etnik menjadi momentum yang sangat besar bagi elit dan kelompoknya untuk mengekpresikan berbagai kepentingan. Dalam keadaan yang diskriminatif, distribusi sumberdaya yang tidak merata dan kekuasaan yang tidak adil tersebut memberikan konstribusi kepada semakin menguatnya identifikasi etnik dalam gerakan politiknya.

\section{Orientasi Budaya sebagai Strategi Politik}

Dalam suatu Negara yang demokratis, identitas budaya etnik dalam politik tidak hilang, dan biasanya melarut dalam berbagai lembaga politik yang ada. Kondisi ini mendorong gerakan penguatan budaya etnik yang berorientasi politik. Selama pemerintahan nasional dan daerah menjalankan pelayanannya dan mengalokasikan sumberdaya yang ada secara adil maka gerakan etnik tidak terlalu signifikan. Namun manakala ada perlakuan yang tidak adil, hak-hak social dan politik terabaikan serta kepentingan kelompok tidak dapat diakomodasi, maka pemimpinpemimpin kelompok tersebut berjuang untuk memperoleh hak dan sumberdaya yang adil, dan pada masa yang sama etnik dan etnisitas akan wujud sebagai instrumen untuk 
mencapai tujuan sosial, ekonomi dan politiknya yang berbeda dengan roh budaya yang semestinya.

$$
\text { Strategi politik menggunakan }
$$
orientasi budaya ini sebenarnya strategi yang rasional di Kalimantan Barat. Hal ini karena hegemoni etnik yang dijalankan oleh elit etnik penguasa (Kristianus, 2011). Budaya telah menjadi semacam pakaian. Dengan memanipulasi budaya itulah kemudian penguasa memelihara dan menguatkan kekuasaannya.

Dalam konteks bagaimana gerakan politik identitas etnik atau etnisitas sebagai reaksi terhadap kebijakan pemerintahan di Kalimantan Barat saat ini, kelihatannya sejalan dengan pandangan Gregory dan Ellinwood (dalam Janowitz, 1985) ${ }^{35}$ bahwa kebijakan pemerintahan nasional merupakan suatu variabel bebas (Idependent Variable), sedangkan reaksi etnik merupakan variable terikat (Dependent Variable) dari perkembangan keadaan politik diperingkat nasional dan daerah. Sesungguhnya akar dari masalah etnik dan etnisiti menurut mereka harus dicari pada kebijakan pemerintahan pusat dan daerah, dan bukan pada reaksi etnik itu sendiri. Perubahan kebijakan pemerintahan pusat, akan mempunyai pengaruh langsung pada penyelesaian masalah menguatnya politik etnik dan etnisitas. Gregory dan Ellinwood menvisualisasikan paradigma

35 Ann Gregory dan C Witi Ellinwood (1985). Pengendalian Etnis dan Rekrutmen Calon Prajurit Militer di Asia Selatan dan Asia Tenggara. Dalam Morris Janowitz, ed. Hubungan-Hubungan Sipil-Militer Perspektif Regional. Bina Aksara, Jakarta. hubungan etnik dengan pemerintahan tersebut sebagai berikut:

Masalah yang perlu memperoleh perhatian adalah representasi kelompok etnik dalam jajaran elite pemerintahan. Karena permasalahan elite dengan sendirinya berasal dari salah satu etnik, maka ia dapat membawa prasangka etniknya sendiri ke dalam jabatan yang ditempatinya. Oleh sebab itu, menurut Gregory, etnik yang over represented akan menghadapi kecemburuan dari etnik yang under represented. Gurr (1993), dengan konsep relative depreation juga berpendapat, bahwa dari hasil kajiannya mengenai berbagai kelompok etnik dan komunal yang aktif dalam berpolitik menunjukkan, bahwa mobilisasi dan strategi mereka didasarkan pada interaksi antara kedua faktor iaitu, reaksi emosional dan merupakan hasil dari kalkulasi politik strategis.

Kemudian menurut Gurr, ada empat faktor yang sangat menentukan intensitas kekecewaan dan potensi untuk kelompok etnik melakukan tindakan politik iaitu; pertama, seberapa besar peringkat keterbelakangan atau penderitaan kolektif kelompok komunal tersebut jika dibandingkan dengan kelompok-kelompok lain. Semakin besar perbedaan keadaan antar kelompok itu, maka semakin kuat alasan untuk kecewa dan semakin kokoh mereka memiliki kepentingan bersama untuk melakukan tindakan kolektif. Kedua, kuatnya perasaan identitas kelompok. Kekecewaan kelompok dan potensi untuk mengartikulasikan kekecewaan itu secara 
politik tergantung pada kekuasaan identitas kelompok itu. Identitas kelompok biasanya akan sangat kuat pada masyarakat komunal yang merasa terancam. Ketiga, derajat kohesi dan mobilisasi kelompok. Keempat, tindakan represif oleh kelompok-kelompok dominan. Tindakan represif yang dilakukan dengan tidak adil akan mendorong munculnya kemarahan dan sikap seringkali curiga. Kelompok-kelompok komunal yang dipaksakan untuk tetap berada dalam status rendah, biasanya menyimpan perasaan kekecewaan yang mendalam terhadap kelompok lain yang lebih dominan.

Pandangan Gregory dan Ellinwood dan Gurr dalam melihat gerakan politik identitas etnik dan etnisitas pada dasarnya dapat dikategorikan sebagai teori colonialism internal seperti Hechter (1975) yang juga memandang gerakan identitas yang berdasarkan pada etnik sebagai suatu bentuk solidariti kaum pinggiran (periphery) yang muncul sebagai reaksi terhadap adanya diskriminasi dan kesenjangan, serta perwujudan kesadaran politik untuk melawan kelompok dominan (centre) yang memiliki privilese ekonomi dan politik. Adanya keridakadilan distribusi sumberdaya dan kekuasaan akan memberikan kesempatan yang besar bagi kelompok periphery tersebut untuk mengekspresikan kepentingan sosial, ekonomi dan politiknya atas dasar etnisitas. Teori ini pada dasarnya melihat identitas politik etnik sebagai bentuk persembunyian (dissimulation), rasionalisasi atau perjuangan kepentingan bersama. Kelemahan teori ini bahwa dia tidak mampu menjelaskan kelahiran dan keberlanjutan solidaritas kelompok. Peran elit politik sangat penting dalam politisasi etnik, dan jika wujud bukan sebagai agregasi kepentingan-kepentingan individual, tetapi strategi kelompok tertentu yang memanipulasi kesetiaan etnik untuk keuntungannya sendiri.

Politik identitas etnik dan etnisitas di Kalimantan Barat saat ini merupakan realitas kolektif yang dikonstruksi berlawanan dengan kelompok lain. Oleh sebab itu sebagian besar pakar menolak pandangan etnisitas sebagai fakta sosial yang terpenting secara universal dan tunggal (invariante), akan tetapi hanya sebagai variable (Cohen, 1974). Etnisitas dianggap hanya sebagai suatu bentuk organisasi atau pembedaan sosial yang bervariasi menurut keadaan (situasional).

Menguatnya identitas Dayak dan Melayu dan bahkan Cina umpamanya, baru dirasakan secara signifikan dalam politik lokal baru pada era reformasi atau pasca berakhirnya rezim kekuasaan Orde Baru pada tahun 1998. Politik identitas etnik dalam kasus di Kalimantan Barat diletakkan sebagai fenomena politik dalam hubungan status dan kekuasaan dan bukan membentuk dasar konseptual etnisitas. Etnisitas dan politik identitas etnik yang terjadi saat ini dilihat sebagai suatu konstruksi sosial yang dimasuki secara situasional, kemudian ditentukan dan dimanipulasi oleh pelaku elit politik. Pendekatan yang lebih cenderung pada 
instrumentalis ini melihat bahwa keperluan akan defenisi identitas etnik dalam politik adalah bersifat material atau untuk mendapatkan kekuasaan.

Yang terpenting dari pemikiran instrumentalism ini adalah untuk mengetahui mengapa orang memilih ciri-ciri etnik untuk mengorganisir persaingan dan konflik sosial, ekonomi dan politik. Apa yang utama dan menjadi objek analisisnya adalah kenyataan konflik, etnisitas dan identitas etnik hanya sebagai satu variabel perilaku politik (political behavioral). Kemudian salah satu kelebihan dari pendekatan ini juga berusaha mengetahui target-target eksternal untuk apa identitas etnik seringkali dimobilisasi. Pandangan Paul Brass (1979) tentang peranan elit dalam kelompok memanipulasi simbol identitas etnik dan Jhon Breuilly $(1993)^{36}$ teori politiknya tentang terbentuknya nasionalisme, merupakan beberapa contoh pemikiran yang bersifat intrumentalism.

\section{Pelembagaan Budaya Etnisitas}

Untuk mempertahankan identitas etniknya, biasanya suatu etnik membentuk suatu organisasi yang umumnya didasarkan pada persatuan etnik, atau merujuk pada

\footnotetext{
${ }^{36}$ Jhon Breuilly (1993). Nationalism and the State, edisi kedua. Manchester. Manchester University Press. Breuilly tidak setuju dengan pendapat yang menyatakan bahawa identity budaya merupakan karakteristik bagi penentu nasionalism. Menurutnya, Nationalism boleh jadi juga merupakan argument yang digunakan oleh subelit untuk memobilisasi rakyat, mengkoordinasikan pelbagai kepentingan yang berbeza di antara kelompokkelompok social dan mengabsahkan tindakan mereka dalam rangka mendapatkan atau mempertahankan kekuasaan di Negara moden.
}

daerah asalnya (Kristianus, 2011). Hal demikian berlaku pula di Kalimantan Barat.

Pada Pemerintahan Orde Baru, etnik Dayak memulainya dengan mendirikan Majelis Adat Dayak (MAD). Etnik Dayak bersatu karena semakin terancam eksistensinya. Pada masa itu komunikasi dan konsolidasi antar tokoh-tokoh Dayak terpelajar meningkat pesat. Organisasi ini merupakan organisasi keetnisan yang pertama dibentuk di Kalimantan Barat. Menurut Iqbal jayadi (2003: 4):

"Orde Baru adalah masa kontemplasi dan konsolidasi bagi Dayak. Dalam masa panjang itu, mereka berusaha semakin menguatkan identitas etnik mereka dengan mengontraskan perbedaan antara Dayak dengan Melayu. Mereka mengidetifikasi dirinya sebagai Kristen, penduduk asli, mayoritas, namun dijajah oleh Melayu yang mereka anggap sebagai Islam, pendatang dan minoritas. Mereka mendirikan berbagai organisasi sosial-politik dan ekonomi yang berusaha memberdayakan kumpulan etniknya. Beberapa belas tahun kemudian, pemberdayaan tersebut berhasil mentransformasikan dirinya sebagai suatu gerakan politik. Dengan berbagai ancaman kekerasan, mereka melakukan demo menentang HPH dan perkebunan, dan puncaknya terjadi ketika mereka berhasil memaksakan pemerintahan untuk mengangkat seorang Dayak sebagai bupati sebelum masa Orde Baru berakhir. Secara tidak langsung, berkembangnya pendekatan Dayak yang cenderung 
pada kekerasan adalah disebabkan oleh sikap perusahaan dan pemerintahan sendiri yang hanya memperhatikan satu tuntutan bila satu kumpulan bersikap mengancam."

Majelis Adat Dayak (MAD) berdiri pada 1994 oleh sejumlah Tokoh Politik Dayak di kota Pontianak. Mulanya kehadiran institusi ini sangat erat kaitannya dengan kepentingan para tokoh tersebut dengan Golongan Karya sebuah partai dominan di era tersebut.

Melayu awalnya tidak mempedulikan gerakan politik etnik Dayak. Namun setelah kekerasan etnik Dayak versus Madura pada 1997 berakhir yang kemudian membuat Dayak semakin asertif dan konfiden dalam memperjuangkan kepentingannya, Bukan hanya dalam politik, melainkan juga sosiokultural. Mereka yang berasal dari kelompok etnik terakhir ini memberikan tanggapan dengan menegaskan bahwa mereka juga merupakan penduduk asli, mayoritas dan juga mengembangkan konsepsi bahwa Dayak dan Melayu adalah saudara, dan bahwa menjadi Islam tidak berarti Dayak kehilangan identitasnya. Lebih jauh Melayu juga mengembangkan berbagai organisasi etnik Kemelayuan dan hukum adat Melayu, seperti MAS Bayu (Majelis Adat dan Seni Budaya Melayu, Lembaga Adat dan kekerabatan Melayu (lembayu), dan Persatuan Forum Komunikasi Pemuda Melayu (PFKPM).

MAS-Bayu, sebenarnya telah didirikan tahun 1995 di Sambas dan
Ketapang $^{37}$. Tetapi aktivitas lembaga ini tidak menonjol. Tahun 1999 mereka mendirikan Lembaga Adat dan Kekerabatan Melayu (Lembayu) dan PERMAK (Persatuan Melayu Kalimantan Barat), basis kedua institusi ini ialah Keraton Kadriah Pontianak, tujuan pendiriannya ialah untuk meningkatkan martabat kesultanan Melayu sepeninggal Sultan Hamid II.

Selanjutnya, Majelis Adat Budaya Melayu $(\mathrm{MABM})^{38}$ didirikan pada tahun 1997, yaitu hampir empat tahun setelah MAD didirikan. Isu yang melatarbelakangi berdirinya MABM Kalimantan Barat tahun 1997, salah satunya ialah perlunya perhatian terhadap kesejahteraan masyarakat Melayu . Selain itu, keberadaan MABM diharapkan dapat mengawal persoalan adat dan budaya sehingga dapat diwariskan kepada generasi muda. Aktivitas menonjol yang dilakukan MABM sejauh ini adalah menggelar festival Budaya Melayu setiap tahun dan membangun Rumah Melayu.

Dari uraian diatas, dapat dikatakan bahwa Orde Baru adalah masa dimana politik identitas Dayak terkonsolidasi. Dengan adanya peminggiran yang sistimatis mereka kemudian bersatu. Masa Orde Baru juga dapat dikatakan bahwa etnik Melayu kembali

\footnotetext{
${ }^{37}$ Baca, Akcaya pada 18 November 1995, Majelis Adat dan seni Budaya Melayu terbentuk di Ketapang.

${ }^{38}$ Lihat Akcaya, April 22, 1997, dibentuk Majelis Adat Budaya Melayu Kalbar, seterusnya dterbitkan dua artikel di Akcaya yang memberi sokongan terhadap penubuhan MABM iaitu pada 19 Agustus 1997 dengan tajuk "Demi bangsa, Negara dan Umat Manusia, Artikel pada 20 Agustus 1997 dengan tajuk" Melayu Siapakah dia?. Kedua artikel ditulis oleh DR Chairil Effendi sekarang Rektor Universitas Tanjungpura Pontianak.
} 
menduduki posisi strategis pada pemerintahan dan politik di Kalimantan Barat.

\section{Kesimpulan}

Muatan politik identitas etnik dalam Pilkada serentak tahun 2015 ini di Kalimantan Barat sangat kental. Dari tujuh Kabupaten yang menyelenggarakan Pilkada, semual calon yang diusung partai dan perseorangan semuanya berbasis etnisitas. Politik lokal yang bermuatan politik identitas ini melibatkan dua etnik yang merupakan penduduk asli di Kalimantan Barat yaitu etnik Dayak dan Melayu dan etnik Jawa yang berasal dari transmigrasi. Keadaan persaingan ketiga etnik ini menjadi lebih terbuka pada era otonomi daerah sekarang ini yang dipicu oleh pemilihan kepala daerah secara langsung.

Persaingan ini terjadi karena sejarah mencatat bahwa elit etnik yang berkuasa menjalankan hegemoni etnik atas etnik lain. Paparan di atas menunjukkan bahwa politik identitas etnik telah menjadi orientasi budaya etnik. Untuk menunjang hal ini budaya etnik telah dilembagakan, maka lembaga seperti Majelis Adat Dayak dan Majelis Adat Budaya Melayu adalah strategi penguatan politik identitas.

\section{Daftar Pustaka}

Adrian, F. (2014). Identitas Etnis dalam Pemilihan Kepala Daerah "Studi Pemilihan Gubernur DKI Jakarta tahun 2012". Skripsi, Prodi Ilmu
Politik FISIP, Universitas Islam Negeri Syarif Hidayatullah, Jakarta.

Ashar, A. (2014). Etnisitas dalam Pilkada Kolaka Utara tahun 2012, Skripsi, Prodi Ilmu Politik, Universitas Hasanudin, Makasar.

Amitai, E. (1961). A comparative analysis of complex organizations.

Barth, F. (1998). Ethnic groups and boundaries: The social organization of culture difference. Waveland Press.

Brass, P. R. (2000). Elite groups, symbol manipulation and ethnic identity among the Muslims of South Asia. Nationalism: Critical Concepts in Political Science, 3, 879-911.

Breuilly, J. (1993). Nationalism and the State. Manchester University Press.

Cohen, A. (1974). Introduction: The Lesson of Ethnicity" i Abner Cohen (red.) Urban Ethnicity.

Firmansyah, D. (2010). Peran Politik Etnis dalam Pilkada, Studi atas PILGUB Provinsi Bengkulu tahun 2005, Skripsi, Universitas Islam Sunan Kalijaga, Yogyakarta.

Gregory, A., \& Ellinwood, C. W. (1985). Pengendalian Etnis dan Rekrutmen Calon Prajurit Militer di Asia Selatan dan Asia Tenggara. HubunganHubungan Sipil-Militer Perspektif Regional. Bina Aksara, Jakarta.

Hechter, M. (1999). Internal Colonialism: The Celtic Fringe in Bristish National Development. Transaction Publishers. 
Jayadi, I. (2003). Konflik etnik di Kalimantan Barat. Universitas Indonesia.

Katzenstein, P. J. (1996). The culture of national security: Norms and identity in world politics. Columbia University Press.

KPUD-Kalimantan Barat. (2015).

Pengumuman Penetapan Calon Bupati-Wakil Bupati 2015.

Kristianus (2011). Hubungan etnik di Kalimantan Barat. Disertasi. Universiti Kebangsaan Malaysia..

Nawawi, M., \& Anriani, H. B. Dinamika Etnisitas dan Konflik Politik pada Pemilukada.

Shamsul, A. B. (2000). pembentukan identity sebagai Fenomena Sosial Satu Komentar Konseptual dan Emperikal. In Makalah seminar "Mencermati Fenomena Dayak Islam di Kalimantan Barat”, anjuran STAIN, Pontianak, Indonesia (Vol. 12).

Von Beyme, K. (1996). Biopolitical ideologies and their impact on the new social movements. Public Policy And Social Welfare, 19, 113-132. 